\begin{tabular}{|c|c|c|}
\hline $\begin{array}{l}\text { 2. To: (Receiving Organization) } \\
\text { Distribution }\end{array}$ & $\begin{array}{l}\text { 3. From: (Originating Organization) } \\
\text { Immobilized Waste Storage and } \\
\text { Disposal }\end{array}$ & $\begin{array}{l}\text { 4. Related EDT No.: } \\
624536\end{array}$ \\
\hline $\begin{array}{l}\text { 5. Proj./Prog./Dept./Div.: } \\
\text { W-464, Immobilized High- } \\
\text { Level Waste Interim Storage }\end{array}$ & $\begin{array}{l}\text { 6. Design Agent: } \\
\text { P.J. Mouette }\end{array}$ & $\begin{array}{l}\text { 7. Purchase Order No.: } \\
\text { N/A }\end{array}$ \\
\hline \multirow{2}{*}{\multicolumn{2}{|c|}{$\begin{array}{l}\text { 8. Originator Remarks: } \\
\text { This document is transmitted for approval. }\end{array}$}} & $\begin{array}{c}\text { 9. Equip./Component No.: } \\
\text { N/A }\end{array}$ \\
\hline & & $\begin{array}{c}\text { 10. System/Bldg./Facility: } \\
\text { N/A }\end{array}$ \\
\hline \multirow{3}{*}{\multicolumn{2}{|c|}{ 11. Receiver Remarks: 11A. Design Basel ine Document? [] Yes $[X]$ No }} & $\begin{array}{l}\text { 12. Major Assm. Dwg. No.: } \\
\text { N/A }\end{array}$ \\
\hline & & $\begin{array}{l}\text { 13. Permit/Permit Application No.: } \\
\text { N/A }\end{array}$ \\
\hline & & $\begin{array}{l}\text { 14. Required Response Date: } \\
6 / 5 / 98\end{array}$ \\
\hline
\end{tabular}

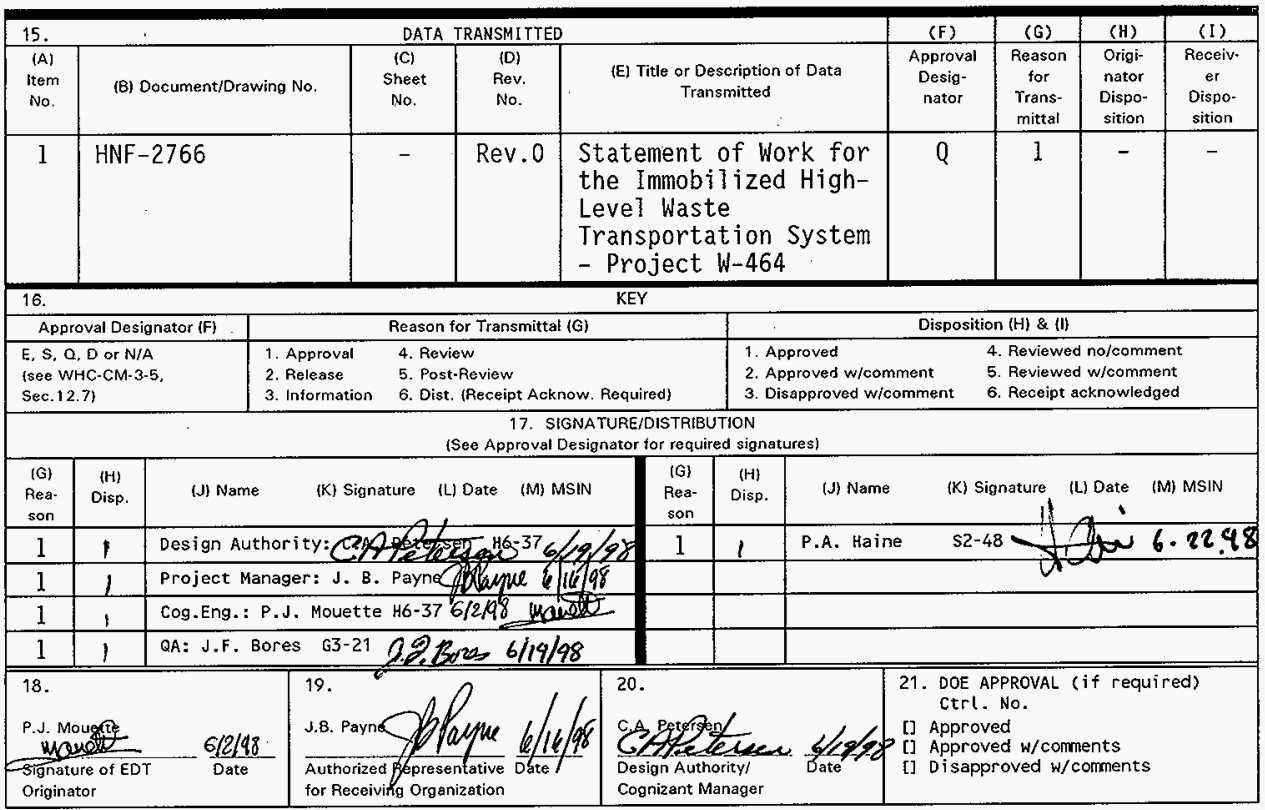




\section{STATEMENT OF WORK FOR THE IMMOBILIZED HIGH-LEVEL WASTE TRANSPORTATION SYSTEM, PROJECT W-464}

P. Mouette

Numatec Hanford Corporation, Richland, WA 99352

U.S. Department of Energy Contract DE-AC06-96RL13200

$\begin{array}{llll}\text { EDT/ECN: } & 624536 & \text { UC: } 721 \\ \text { Org Code: } & 73400 & \text { Charge Code: } & \text { D4NKV } \\ \text { B\&R Code: } & \text { EW3130010 } & \text { Total Pages: } & 15\end{array}$

Key Words: Radioactive waste on-site transportaiton, IHLW

Abstract: This Statement of Work asks Waste Management Federal Services, Inc., Northwest Operations, to provide Project W-464 with a Design Criteria Document, plus a 1 ife-cycle schedule and cost estimate for the acquisition of a transportation system (shielded cask, truck, trailer) for IHLW on-site transportation.

TRADEMARK DISCLAIMER. Reference herein to any specific commercial product, process, or service by trade name, trademark, manufacturer, or otherwise, does not necessarily constitute or imply its endorsement, recommendation, or favoring by the United States Government or any agency thereof or its contractors or subcontractors.

Printed in the United States of America. To obtain copies of this document, contact: Document Control Services, P.O. Box 950, Mailstop H6-08, Richland WA 99352, Phone (509) 372-2420; Fax (509) 376-4989.

$\frac{\text { Lawis }}{\text { Retease Approval }} \frac{-24-98}{\text { Date }}$

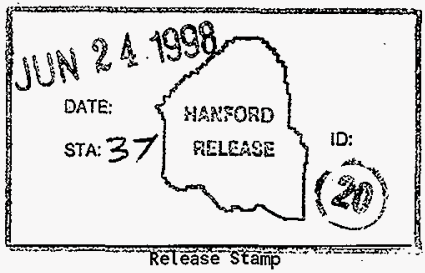


HNF-2766, Rev.0

\section{STATEMENT \\ OF WORK FOR THE IMMOBILIZED \\ HIGH-LEVEL WASTE TRANSPORTATION SYSTEM}

PROJECT W-464

June 1, 1998

Prepared for

U.S. Department of Energy

Richland, Washington 
HNF-2766, Rev. 0

Project Hanford Management Contract Technical Representative Approvals

Document Title: Statement of Work for the Immobilized High-Level Waste

Transportation System, Project W-464

Prepared by:

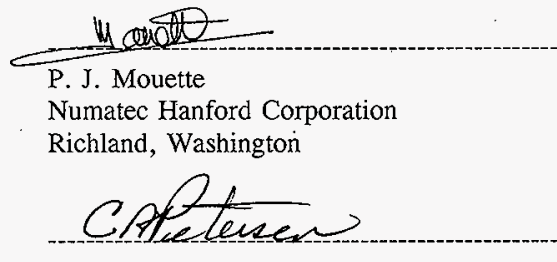

C. A. Petersen

$6 / 2198$

Date

Reviewed by:

Numatec Hanford Corporation

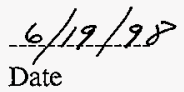

Richland, Washington

Approved by:

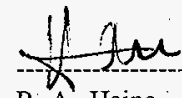

6.22 .98

P. A. Haine

Date

Numatec Hanford Corporation

Richland, Washington 
Table of Contents

Table of Contents $\ldots \ldots \ldots \ldots \ldots \ldots \ldots \ldots \ldots \ldots \ldots \ldots$ ii

LIst of Tables $\ldots \ldots \ldots \ldots \ldots \ldots \ldots \ldots \ldots \ldots \ldots \ldots \ldots \ldots$ iv

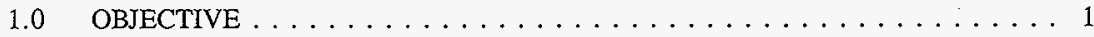

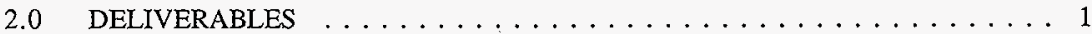

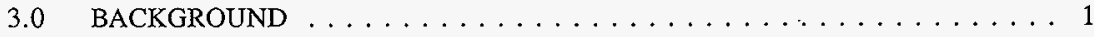

3.1 PROJECT STATUS AND MASTER SCHEDULE $\ldots \ldots \ldots \ldots \ldots$

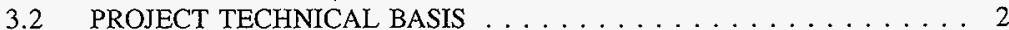

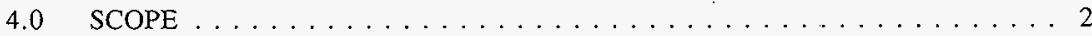

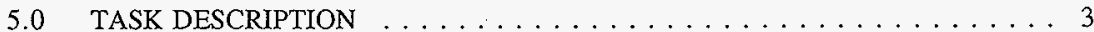

6.0 DOCUMENT OUTLINE ......................... 4

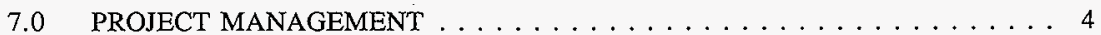

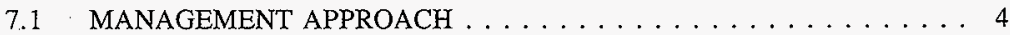

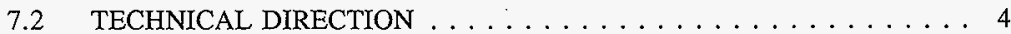

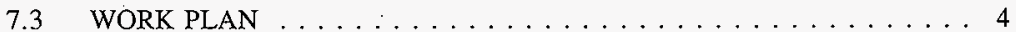

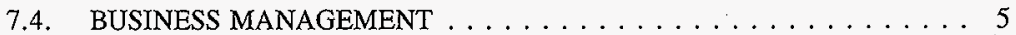

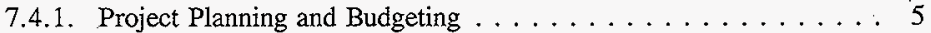

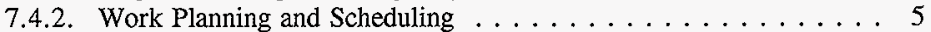

7.4.3. Management Reports, Meeting, and Reviews . . . . . . . . . . 6

7.5. DOCUMENT REQUIREMENTS .................. 6

7.5.1. General Data . . . . . . . . . . . . . . . . . . . 6

7.5.2. Document Control ..................... 7

7.5.3. Document Identification and Format . . . . . . . . . . . 7

7.5.3.1. Numbering System ................. 7

7.5 .3 .2 Format . . . . . . . . . . . . . . . 7

7.5.3.3 Engineering Sketches ................ 8

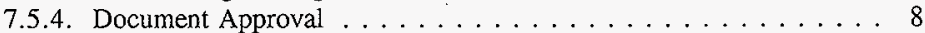

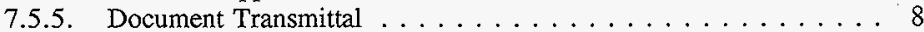

7.5.6. Record Files .................... . . 8

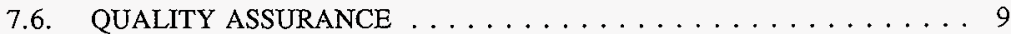

7.6.1. Accessibility for Assessment Purposes ............... . . . . . . . . . .

7.6.2. Sub-tier Contractor QA Programs ................ 9

7.7. SYSTEMS ENGINEERING MANAGEMENT . . . . . . . . . . . 9

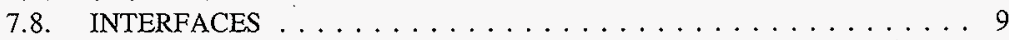


HNF-2766, Rev.0

8.0

REFERENCES

List of Tables

Table $7-1$, Review and Task Completion Dates $\ldots \ldots \ldots \ldots \ldots \ldots$

Table $7-2$, Interfaces . . . . . . . . . . . . . . . . . . . . . 10 
HNF-2766, Rev.0

\subsection{OBJECTIVE}

The objective of this Statement of Work (SOW) is to present the scope, the deliverables, the organization, the technical and schedule expectations for the development of a Package Design Criteria (PDC), cost and schedule estimate for the acquisition of a transportation system for the Immobilized High-Level Waste (IHLW). This transportation system which includes the truck, the trailer, and a shielded cask will be used for on-site transportation of the IHLW canisters from the private vendor vitrification facility to the Hanford Site interim storage facility, i.e., vaults $2 \& 3$ of the Canister Storage Building (CSB). This SOW presents the scope of the work to be performed under the direction of the Project Hanford Management Contract contractor responsible for this project, i.e., Numatec Hanford Corporation Project Office (NHC). The objective of this effort is to establish a program in compliance with the principles delineated in HNF-PRO-154, Rev. 0, Responsibilities and Procedures for all Hazardous Materials.

\subsection{DELIVERABLES}

The contractor is requested to provide the following by September 30, 1998:

a) A Package Design Criteria (PDC) including a description of the major design features and the results of a preliminary safety assessment for the system (see sections 5.0 and 6.0 for details)

b) A work plan which presents the overall schedule and cost estimate for the acquisition of the system until start of operation in June 2002.

In addition to these deliverables, the contractor should be able to provide a technical support to the project office, NHC, for miscellaneous analysis and special studies.

\subsection{BACKGROUND}

\subsection{PROJECT STATUS AND MASTER SCHEDULE}

Project W-464 is a FY 2000 line-item project validated in FY 1998. A Conceptual Design Report (CDR) (HNF, 1998a), a Preliminary Safety Evaluation (PSE) (Appendix G of the CDR), and a complement to the DRD (WHC, 1996) regarding preliminary design requirements associated with the 4.5 meter canister (HNF, 1997a) were completed in FY 1998 and should be used as the principle basis for the work defined in this SOW. 
Detail design for the facility is planned to take place in FY 2000, and construction in FY 2001, in order to meet the start of operation deadline in June 2002. Detailed schedules and background information are documented in Appendix E of the project plan (HNF, 1997b).

The work plan to be generated as part of deliverable b) presented in Section 2.0, should fit this project master schedule (see Section 5.0 for details).

\subsection{PROJECT TECHNICAL BASIS}

The baseline information to be used (radiological inventory, canister characteristics, throughput, preliminary transportation system concept, quality assurance program, etc.) for this task can be found in the following project documentation

- Design Requirement Document (WHC, 1996)

- Conceptual Design Report (HNF, 1998a)

- Preliminary Safety Evaluation (Appendix G of HNF, 1998a)

- Attachment 1 to the DRD, Preliminary 4.5 Meter Canister Conceptual Design

Requirements (HNF, 1997a)

- Project Plan (HNF, 1997b)

If additional information or clarification is needed, refer to the listing of assigned Technical Representatives (TRs) (see Table 7-2). The references called out in this SOW are available upon request.

\subsection{SCOPE}

For this SOW, the scope is limited to the initial phase of operation of the private vitrification plant (Phase I). The transportation system should achieve the time and motion flow diagram requirements defined in the CDR. Another objective is to identify any specific interface requirements between the transportation system, the infrastructure systems (i.e., driveways, roads, etc.) and the facilities (vitrification plant and interim storage facility).

Three kinds of waste are to be packed into the IHLW canisters for transport; glass, cesium free flowing powder from the low-activity waste pretreatment, and non-routine waste constituted of spent melters and glass flush from maintenance activities at the vitrification facility. The design and the safety analysis should account for the worst case that bounds all of the transportation sequences.

The level of detail for these studies will be defined in the work plan to be submitted to and approved by the buyer. 
HNF-2766, Rev.0

\subsection{TASK DESCRIPTION}

The objective is to acquire an on-site transportation system capable of moving the IHLW canisters from the private vendor facility to the interim storage facility by June 2002 . In order to meet this objective, the contractor is requested per this SOW to develop:

1) A Package Design Criteria Document including, but not limited to:

- a list and a discussion of the applicable requirements (Federal and Washington State Laws, codes, standards, and DOE Orders) for normal and off-normal conditions of on-site transfer of radioactive waste

- QA and environmental program to comply with

- a system description and justifications

- preliminary technical and safety assessments of the key drivers for the design, construction, operation and maintenance of the system (e.g., safety classification)

- a packaging (shielded cask) and transportation system (truck and trailer) design criteria (e.g., materials, fabrication methods, packaging dimensions and gross weight, lifting and tiedown attachments, closure, containment, shielding and criticality features, heat removal, maintenance, etc.)

- identification of the uncertainties and items that need further resolution during later design phases

- identification of the interfaces issues between the transportation system and the private vendor vitrification plant and the interim storage facility

This system will comply with applicable sections of Federal and Washington State laws and DOE orders and guidance for onsite transportation. As not intended to travel on public highways, this transportation system is not expected to be licensed under the Department of Transportation (DOT) regulations.

2) A cost and schedule estimate for the following activities, to be reviewed and completed by the contractor:

In FY 1999- design concept phase; preliminary safety evaluation, scoping analysis, conceptual design studies, QA program plan (see Section 7.6), etc. 
HNF-2766, Rev.0

In FY 2000- detailed design and procurement specifications; final design and specifications for procurement, preliminary Safety Analysis Report for Packaging (SARP), etc.

In FY 2001/2002- procurement, construction, testing, final SARP, support to operation for preparation of operating procedures, turn over to operation, etc.

\subsection{DOCUMENT OUTLINE}

The format and content for the different deliverables to be prepared will be documented in a work plan to be submitted by the contractor to the NHC Project Office for approval. The format and content of these documents will be consistent with applicable requirements and normal use for transportation of radioactive waste. The format and content of the Packaging Design Criteria for the MCO Cask, HNF-SD-TP-PDC-030, Rev. 3, may be carried out for this task.

\subsection{PROJECT MANAGEMENT}

\subsection{MANAGEMENT APPROACH}

The U.S. Department of Energy, Richland Operations Office (RL) will be the owner of the IHLW transportation system. Oversight of the project activities will be provided by the Director, RL Waste Disposal Division (WDD). Overall project management will be provided by the TRs. Administration of the contract will be provided by the buyer Contract Administrator (see Table 7-2).

\subsection{TECHNICAL DIRECTION}

The TRs have the responsibility and the authority for technical direction of the contractor's activities within the scope of this SOW. Any changes to the requirements of this SOW, or direction that impacts any of the contract cost/schedule provisions or its terms, must come only from the buyer Contract Administrator.

\subsection{WORK PLAN}

A work plan which reflects the requirements of this SOW shall be prepared and submitted to the buyer for approval. This work plan will present the specific activities, approaches, resource needs, cost and schedule to complete the tasks required in this SOW (including miscellaneous special studies as identified in Section 2.0). The estimated number and type of engineering sketches, specifications, calculations, reports, etc., should be provided as part of this work plan. 


\subsection{BUSINESS MANAGEMENT}

\subsubsection{Project Planning and Budgeting}

The contractor shall provide monthly reports including a Budgeted Cost of Work Performed (BCWP), Budgeted Cost of Work Scheduled (BCWS), and Actual Cost of Work Performed (ACWP) with variances analysis.

\subsubsection{Work Planning and Scheduling}

As defined in Sections 2.0 and 5.0, the contractor shall develop a schedule for the design, procurement, test, and turn over to operation of the transportation system as part of its deliverables. The objective is to start operation by June 2002 to support the privatization effort. The schedule for the acquisition and start of operation of the transportation system should be tied to the project schedule.

The work plan should account for at least a two-week review of the product by the project team, plus RL (as needed), and another two weeks for dispositioning of the comments and making necessary changes to the text. The draft documents will be submitted to the TRs, for informal overall quality review, prior to be submitted to the formal functional review. The work plan is also expected to specify any other review requirements outside of what is usually performed for the facilities. Table 7-1, below, summarizes the required deliverables for review dates.

Table 7-1, Review and Task Completion Dates

\begin{tabular}{||l|l||}
\hline \multicolumn{1}{|c|}{ Deliverables } & Expected dates \\
\hline $\begin{array}{l}\text { Documents submittal for overall quality and } \\
\text { adequacy review }\end{array}$ & $8 / 19 / 98$ \\
\hline Document submittal for functional review & $8 / 26 / 98$ \\
\hline Functional review completed & $9 / 9 / 98$ \\
\hline $\begin{array}{l}\text { Comments dispositioned, text changed, submittal } \\
\text { to the buyer for approval }\end{array}$ & $9 / 23 / 98$ \\
\hline $\begin{array}{l}\text { Completion of Transportation Criteria Document, } \\
\text { cost and schedule estimate for system acquisition } \\
\text { (reviewed and approved by buyer) }\end{array}$ & $9 / 30 / 98$ \\
\hline
\end{tabular}


HNF-2766, Rev. 0

\subsubsection{Management Reports, Meeting, and Reviews}

Along with the monthly schedule and budget reports specified in Section 7.4.1 above, a brief progress status of the task will be provided to NHC. This status should present the accomplishments during the given period as well as any issues that may have surfaced.

Monthly meetings shall be held to discuss the status of the task. The above requested reports could be made verbally during the monthly meetings and then recaptured in the meeting minutes, including as necessary attachments (cost and schedule status).

A kickoff meeting will be held prior to the start of the task. This meeting will provide a forum to discuss any details and issues regarding this SOW, the task order, and work plan.

Informal coordination meetings, including telephone conferences, will be held as necessary between the contractor and the project TRs to discuss various issues as they arise.

\subsection{DOCUMENT REQUIREMENTS}

Record documents and contract documents will be generated during the course of this task. Record documents are those end-item documents required by this SOW. Contract documents are those documents that implement the contract and include the contract and all requirements, references, records, and other related documents.

\subsubsection{General Data}

All engineering deliverables shall be prepared using SI units. Sketches shall be prepared using a computer-aided design and drafting (CADD) process. Any exceptions shall be identified and submitted to the TRs for approval. Software used for CADD tools must be available to the TRs. If a contractor proprietary software is used, the TRs shall have free access to it to the extent legally possible. All commercial software and user rights purchased by the project shall be transferred to the TRs on or before the task completion.

Full-size sketches shall be 71 by $102 \mathrm{~cm}$ ( 28 by 40 in.). Reduced sketches can be 36 by $50 \mathrm{~cm}$ ( 14 by $20 \mathrm{in}$.) if mutually agreed upon by the TR and the contractor. Sketches included in topical reports can be 28 by $43 \mathrm{~cm}$ ( 11 by 17 in.) or 21 by $28 \mathrm{~cm}(8.5$ by 11 in.). Sketch sizes other than those listed may be accepted on a mutually agreed upon basis. Reproducibles for sketches shall be furnished by the contractor pending approval by the TRs. 


\subsubsection{Document Control}

Preparation, identification, approval, transmittal, and final disposition of record documents shall conform to guidance given by the TRs. If there is no guidance, use of the contractor's established procedures or special instructions is required. Use of contract documents shall be controlled in accordance with the contractor's established procedures or special instructions.

\subsubsection{Document Identification and Format}

7.5.3.1. Numbering System. The contractor is required to use the Hanford Site Controlled Document numbering system for all documents, technical reports, sketches and specifications, etc. The numbers will be provided to the contractor by the TRs or its designee.

7.5.3.2 Format. Each deliverable record document shall show the following

- Project and contract identification

- $\quad$ IHLW Transportation System

- $\quad$ Project number: W-464

- Contract number: To be determined

- Originating firm's name

- End-item document title

- Document level of approval

- Document identification number (on each page)

- Document descriptive title

- Revision or addendum number or letter (on each page with revised portion of the page indicated)

- Issue or revision date (released documents only)

- Total number of pages and number of each page

- Table of contents and attachments (as needed) 
HNF-2766, Rev.0

- Approval signature and title of responsible person in originating firm (for released documents only).

7.5.3.3 Engineering Sketches. Sketch numbers will be provided by the contractor in accordance with Hanford nomenclature. Each sketch shall include a list of interfacing sketches.

\subsubsection{Document Approval}

All engineering sketches and technical documents submitted to the TRs for review shall first be thoroughly peer reviewed by appropriate members of the contractor's technical staff. The contractor shall have written procedures in place that delineates the requirements for reviewing, checking, technical editing, and approval of documents before issuance.

Acceptance by the TRs is the act of reviewing an activity or document and acknowledging that it may be used for the purpose intended at that time. Acceptance by the TRs does not ensure that future changes will not be required and does not convey or imply approval or assumption of responsibility for the activity or document. The originator remains fully responsible for all aspects of the activity or document, for fulfilling all specifications, and for any other obligation or liability otherwise arising under a specification, agreement, or contract.

\subsubsection{Document Transmittal}

Unless otherwise agreed upon, transmittal of record documents shall include one reproducible, 20 copies, and one electronic copy. For documents larger than 21 by $28 \mathrm{~cm}$ ( 8.5 by 11 in.) full-size, photo-quality reproducible shall be included. Transmittal of record documents produced electronically shall include indices that identify directory and data set file names. Transmittals shall be prepared consistent with Section 3.5.3.2 and in accordance with DOE Order 1324.5B, Records Management Program (DOE 1995).

\subsubsection{Record Files}

Record files, those documents that describe or support the project technical baseline (e.g., requirements, calculations, sketches) with current and previous revisions shall be maintained for record documents in accordance with an approved configuration control program. The contractor shall provide a list of record documents to the TRs for concurrence. At the conclusion of the task, the TRs will advise the contractor of the file's disposition. The contractor shall keep duplicate copies of data to meet code or legal requirements.

\subsection{QUALITY ASSURANCE}


HNF-2766, Rev.0

The contractor will implement the PHMC Quality Assurance system, including document control. The cost and schedule to be prepared as part of the deliverable b) in Section 2.0, should include the development of a Quality Assurance Program Plan based on the DOE Office of Civilian Radioactive Waste Management (OCRWM), Quality Assurance and Requirements and Description (QARD).

\subsubsection{Accessibility for Assessment Purposes}

The contractor shall allow access to all documents, files, and workstations for purposes of assessment or surveillance of activities by the Project Hanford Management Contract (PHMC) or their designated agents. The contractor shall provide support, as requested, for assessments or surveillance conducted by the PHMC.

\subsubsection{Sub-tier Contractor QA Programs}

Sub-tier contractors to the main contractor shall have Quality Assurance programs applicable to their portion of the work scope. Sub-tier contractors' QA programs must implement the relevant requirements of HNF-MP-599, Part 2, Sections 1-9, and the contractor shall approve any such sub-tier contractor programs.

\subsection{SYSTEMS ENGINEERING MANAGEMENT}

The contractor shall plan and manage, at a minimum, the following systems engineering elements as a part of this task: analysis of DRD requirements and traceability into the PDC, design concept, detailed design, specifications, procurement, and testing documentation; identification of alternatives considered for each major subsystem and the basis for alternative selection; identification of enabling assumptions that could influence the scope, cost, or schedule; and identification of risks associated with the design and construction that could influence scope, cost, or schedule. These elements shall be applied to deliverables provided by the contractor.

\subsection{INTERFACES}

The Technical Representatives (TRs) and their areas of responsibility within the project office are listed in Table 7-2. These TRs are the primary POCs for the contractor from whom technical directions should be taken. 


\begin{tabular}{||l|l|}
\hline TRS Names & Responsibilities \\
\hline J. B. Payne & Project Manager \\
\hline C. A. Petersen & Design Authority \\
\hline R. B. Calmus & Project Engineer \\
\hline P. J. Mouette & Technical Lead for this task \\
\hline B. E. Voisin & Contract Administration \\
\hline
\end{tabular}

The contractor will work in close co-ordination with the project design team, specifically with the assigned TRs listed above for this task. Formal monthly status will be provided.

Regarding the schedule for the development, review and approval of the Safety Basis Documentation; Preliminary SARP, Final SARP, controls and administrative procedures related to safety, the contractor will interface with TWRS Nuclear Safety and Licensing, Operation and Project Safety Support (C.E. Leach), in order to co-ordinate both safety analysis efforts developed for the facility and the transportation system.

\subsection{REFERENCES}

HNF, 1997a, Attachment 1 to the DRD, 4.5 Meter Canister Conceptual Design Requirements, R. B. Calmus, SGN Eurisys Services Corporation, September 1997.

HNF, 1997b, HNF-1751, Rev.0, TWRS Retrieval and Disposal Mission - Immobilized HighLevel Waste Storage Plan, R. B. Calmus, SGN Eurisys Services Corporation, December 1997.

HNF, 1998a, HNF-2298, Rev.0, Conceptual Design Report, Immobilized High-Level Waste Interim Storage Facility (Phase 1). Project W-464, Numatec Hanford Corporation, March 23, 1998.

HNF-PRO-154, Rev.0, Responsibilities and Procedures for all Hazardous Material Transportation and Packaging.

WHC, 1996, WHC-SD-W464-DRD-012, Rev.0, Design Requirement Document for Immobilized High-Level waste Interim Storage. 
HNF-2766, Rev. 0

WHC, 1996, WHC-SD-W464-DRD-012, Rev.0, Design Requirement Document for Immobilized High-Level waste Interim Storage.

HNF-SD-TP-PDC-030, Rev.3, Packaging Design Criteria for the MCO Cask. W. S. Edwards, Rust Federal Services of Hanford Inc. January 30, 1997.

DOE Order 1324B, Record Management Program (DOE 1995).

HNF-MP-599, Part 2, Section 1-9, Contract Project Hanford Quality Assurance Program Description. 


\section{DISTRIBUTION SHEET}

\begin{tabular}{|c|c|c|c|c|c|}
\hline To & \multirow{2}{*}{\multicolumn{3}{|c|}{$\begin{array}{l}\text { From } \\
\text { Immobilized Waste Storage and } \\
\text { Disposal }\end{array}$}} & \multicolumn{2}{|l|}{ Page 1 of 1} \\
\hline DISTRIBUTION & & & & \multicolumn{2}{|c|}{ Date $06 / 23 / 98$} \\
\hline \multicolumn{4}{|c|}{ Project Title/Work Order } & \multicolumn{2}{|c|}{ EDT No. 624536} \\
\hline W-464, Immobilized Hig & ste Interim St & rage & & \multicolumn{2}{|l|}{ ECN No. $N / A$} \\
\hline Name & MSIN & $\begin{array}{l}\text { Text } \\
\text { With All } \\
\text { Attach. }\end{array}$ & Text Only & $\begin{array}{l}\text { Attach./ } \\
\text { Appendix } \\
\text { Only }\end{array}$ & $\begin{array}{c}\text { EDT/ECN } \\
\text { Only }\end{array}$ \\
\hline
\end{tabular}

\section{Cogema Engineering}

R. B. Calmus

DE\&S Hanford, Inc.

S. S. Gahir

C. E. Leach

Fluor Daniel Northwest. Inc.

J. B. Payne

Lockheed Martin Hanford Corp.

J. F. Bores

K. C. Burgard

M. L. Deffenbaugh

T. A. Grillo

R. J. Murkowski

S. M. 0'Toole

R. W. Root

J. A. Voogd

Lockheed Martin Services, Inc.

Project.Files (2)

TWR-DIMC

Numatec Hanford Corporation

P. A. Angelier

P. A. Haine

P. J. Mouette

C. A. Petersen

B. E. Voisin
H6-37 $\quad X$

$\begin{array}{ll}R 1-43 & X \\ R 1-49 & X\end{array}$

H6-37 X

G3-21

H6-37

H6-37

H6-37

H6-37

G3-21

H6-12

H6-37

$X$
$X$
$X$
$X$
$X$
$X$
$X$
$X$

H6-08

H6- 15

$\stackrel{x}{x}$

S7-82

R3-47

H6-37

H6-37

H7-08 